\title{
7,62 mm-es AMP puskagránátlövő gépkarabély u.ressz
}

\section{A GRÁNÁTLÖVŐ TÖLTÉNY}

A gránátlövő töltényt (9. ábra) és a 43M gyakorlótöltényt (általánosan ismert nevén $43 \mathrm{M}$ vaktöltény) tilos felcserélve használni. A gránátlövő töltény - ezüstszínű csúcsa miatt - nem összetéveszthető a gyakorlótölténnyel.

A gránátlövő töltet lőportartalma 2,04 g piroxilines (egybázisú nitrocellulóz) 1 lyukú csőlőpor (3200kJ/kg égéshővel). Ez a 43M PSz acélmagvas élestöltény lőporadagjának $127,5 \%$-a. Ez a mennyiség még normál csőhossznál is akkora gáznyomást produkál a gázátömlő furatnál, hogy a mozgó alkatrészek és a tok maradandó szerkezeti elváltozást szenvednének gázcsap lezárása hiányában. A gránátlövő töltény tömege $9 \mathrm{~g}$. Csomagolása: polietilén tasakban, egyenként csomagolva, a puskagránátok polisztirol hab csomagolásába ágyazva.

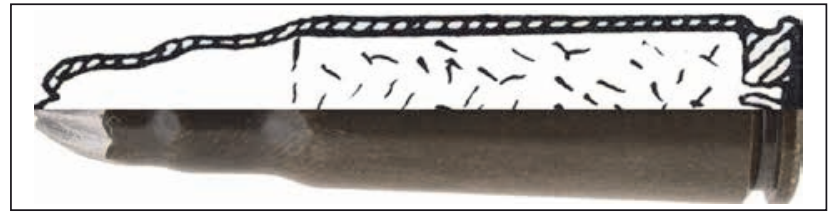

9. ábra. Gránátlövő töltény

\section{PGK ÉS PGR PUSKAGRÁNÁTOK}

A puskagránátok moduláris jellegűek, a puskagránát részei egymáshoz menetes illesztéssel kapcsolódnak. Az éles gránátok teljes egészükben zöldek. A PGK, PGR puskagránátok azonos szerelt hajtóművel (10. ábra) vannak ellátva. Ez gyártási szempontokból előnyös, mivel csak egyfajta terméket kell gyártani.

A hátsó stabilizáló szárnyak a $68 \mathrm{M}$ páncéltörő gránátvetőéhez hasonlóak (ez a konstrukció szolgált alapul), a szerkezet $6 \mathrm{db} 9^{\circ}$-ban döntött stabilizátor szárnyat használ. A rakétahajtómű egy darab kétbázisú, egylyukú csőlőporral üzemel. A fúvókák $30^{\circ}$-ban térnek el radiálisan és $4^{\circ}$ ban jobbra a tengelyhez képest (tangenciálisan), ezzel biztosítják a legfeljebb 25-30 fordulat/másodperces forgást a stabilizátor szárnyakkal együtt. A forgás sebességé-

10. ábra. Szerelt hajtómű

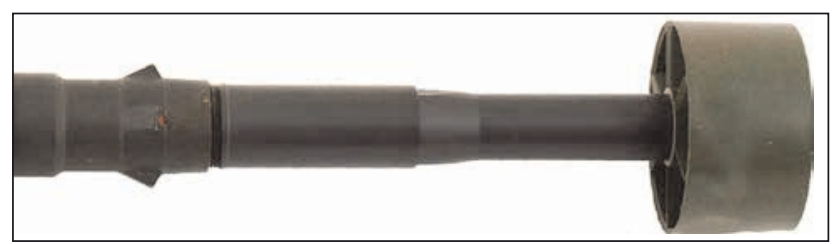

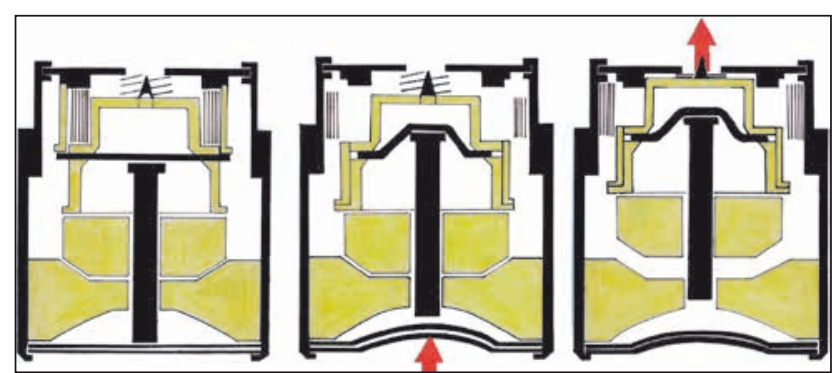

11. ábra. A DC-1M gyújtó müködése

nek a szükséges minimum környékén tartása fontos, mivel a kumulatív sugár kialakulására a magasabb fordulatszámok kedvezőtlenül hatnak (a repeszgránátoknál ilyen probléma nincs). Az indítócsövet lövés előtt a PGK puskagránátnál polisztirol habdugó, a PGR puskagránátnál müanyag toldat óvja a szennyeződésektől, amelyet a gránáton lévő „T" alakú nyúlványra lehet rögzíteni.

A szerelt hajtóműben található a $\mathrm{DC}-1 \mathrm{M}$ gyújtó, amely egy mechanikus csapódó gyújtó tekercsrugós késleltetővel, amely biztosítja a 15 méteres lepelbiztonságot (11. ábra). A puskagránát lövésnél a kilövőtöltény lőporának égéséből származó nagy nyomású gázok benyomják a DC-1M gyújtó fenékrészén található membránt. Emiatt a hosszirányú tengely deformálja a biztosító acélszálat, aminek hatására a rugóbiztosító-gyűrű felszabadul és lecsúszik a gyorsulás hatására. A tekercsrugó kitekeredik és az ütőtömb, valamint az ütőszeg szabaddá válik. Repülés közben az ellenrugó biztosítja, hogy ne történjen korai elműködés és robbanás.

A rakétahajtómü indítása a kivetés után némileg késleltetve történik. Az indítótöltény gázainak hatására a DC-1M gyújtó élesedik és a rakétalőpor gyullasztó lőpora meggyullad (ez adja a minimális késleltetést). A rakétalőpor begyulladásakor a rakétahajtómű $4 \mathrm{db}$, kifelé $30^{\circ}$-ban elhelyezett fúvókáján kiáramló gázok kilökik a bennük levő polisztirol golyókat. Ekkor a gránát még az indítócsövön tartózkodik, a lövész biztonságát a fúvókák elhelyezése biztosítja. A gránátot ebben a fázisban egyszerre gyorsítja a kilövőtöltény gáznyomásából származó erő és a rakétahajtómű tolóereje. A csőtoldatról való lelépéskor a rakétahajtómű még mindig tolóerőt fejt ki, viszont a kilövőtöltény gázai a csőtorkolaton történő kiáramláskor már csak részben gyorsítják a gránátot és a kiáramlás során a stabilizátor szárnyakra hatva mindenképpen minimálisan kitérítik a célzott röppályáról. Ez a szöghiba véletlenszerű eloszlású, és a működő rakétahajtómű erre a hibás röppályára stabilizálja a gránátot. A rakétahajtómű gyorsítási szakasza körülbelül 0,10-0,15 s-ig tart, ezalatt az idő alatt a teljes lő-

\footnotetext{
Hadnagy. HM Hadtörténeti Intézet és Múzeum, ORCID: 0000-0002-2402-8759
} 


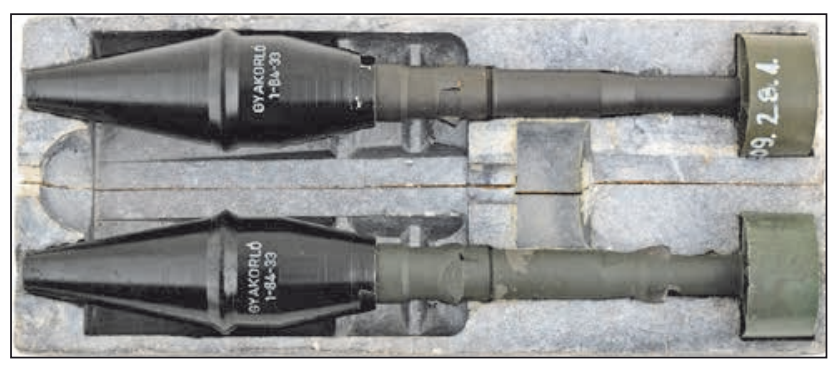

12. ábra. Polisztirol habba ágyazott gyakorló puskagránátok (hiányos hab)

portöltet elég, ezután a gránát ballisztikus pályán mozog. A maximális sebességet $(93 \mathrm{~m} / \mathrm{s}$ ) körülbelül 10 méter után éri el. Az oktató puskagránát maximális sebessége (csak a kilövőtöltény gyorsít) $30 \mathrm{~m} / \mathrm{s}$.

A puskagránátok csomagolása polisztirol habban történik, változó kivitelben. A csomagolóládában $8 \mathrm{db}$ lefóliázott, polisztirol habba ágyazott gránát (12. ábra) található. Egy csomagolóláda tartalma a 24 db PGK és 16 db PGR változattól a $40 \mathrm{db}$ PGR puskagránátos változatig módosulhat. A habbetétben a puskagránátok aránya variálható. Összesen $5 \mathrm{db}$ puskagránát elhelyezésére van lehetőség, ebből három helyen helyezhetők el PGK puskagránátok. A képen látható elrendezésben legfeljebb $2 \mathrm{db}$ PGK és $1 \mathrm{db}$ PGR puskagránát lenne elhelyezhető (vagy $3 \mathrm{db}$ PGR, stb).

Az éles puskagránátokat alapvetően kettő rendszeresített típusú gránátfejjel gyártották. Ezek a kumulatív (PGK) és a repesz (PGR) gránátok voltak.

A PGK gránátfej működési elve (13. ábra) kumulatív hatáson alapul. A töltet peremezett, alumínium testbe foglalt hexogén, a béléskúp anyaga vörösréz és alumínium terelőkúppal van ellátva. Gyutacsa TAT-1T az alumínium csészébe sajtolt tetril detonátor indítására. $A z$ orrkúpon ún. rogyókúpokat alakítottak ki, amelyek becsapódáskor az ideális távolságra csúsznak össze, hogy megfelelő távolságot biztosítsanak a kumulatív sugár kialakulásához.

Becsapódáskor az orrkúp (40-50 mm-t) „berogy”. Nem merőleges becsapódás esetén a rogyókúpok rogyása a béléskúpot előnyösebb helyzetbe pozícionálja. A DC-1M gyújtó ütőszege a tehetetlensége folytán előremozog, és működésbe hozza a gránátot. A töltet detonálásakor kialakuló nyomáshullám miatt a vörösréz béléskúpból kialakul a kumulatív sugár, ami a páncéllemezt „átüti” (kimossa), régebbi terminológia szerint a páncélt „átégeti”.

A repeszgránát repeszképző burkolata az öntött acélköpenye, amely körte alakú. A külső palást csúcsán „T” alakú nyúlvány található, amelyre csatlakoztatható a műanyag toldat, amely szállítási helyzetben az indítócsőben helyezkedik el. Az acélköpeny belső felületén hosszanti és keresztirányú hornyok találhatók, amelyek a repeszképző-

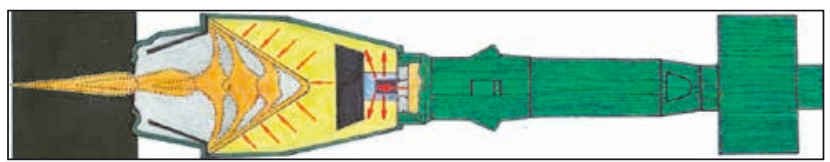

13. ábra. PGK múködés

\section{4. ábra. PGR müködés (műanyag toldat nélkül)}

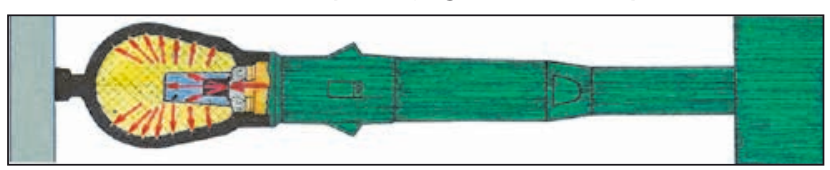

dést segítik elő. Az öntött trotil robbanótöltetben kap helyet a tetril detonátor és a TAT-1T gyutacs. Becsapódáskor a DC-1M gyújtó ütőszege a fentebb is említett módon, tehetetlenségének folytán elindítja a gyújtási láncot (14. ábra). A detonáció hatására az acéltest közel a hornyok mentén törik. A toldat felszerelése jelentősen növeli a tömör leküzdési sugarat. Ez azt jelenti, hogy a gránát a műanyag toldat miatt a föld felett detonál. Ezért jelentős mennyiségű repesz nem a földbe csapódik, mint a toldat nélküli detonációkor. Ez azt eredményezi, hogy több repesz, nagyobb területen képes kifejteni a hatását.

\section{KIKÉPZÉSI GRÁNÁTOK}

A kiképzéshez használt gránátok négy csoportba rendszerezhetők. Az éles gyakorlógránátok harcászati és lőelőkészítő foglalkozásokon használt tömeg és alakhelyes imitációs eszközök, amelyek pirotechnikai résszel rendelkeznek. Jelölésük a gránát neve utáni „-GY” utótag. A gyakorló gránátok azonosak az éles gyakorlókkal, de pirotechnikai elemet nem tartalmaznak. Jelölésük nagybetűs „GYAKORLÓ” felirat. Ezek a csőtoldatra való felhelyezés, célzás, lőelőkészítő foglalkozások megtartása miatt voltak fontosak. A metszetpuskagránátok az anyagismereti foglalkozásokhoz nyújtottak segítséget. Az OPG oktató puskagránátok a puskagránáttal való lövészet fogásainak, a fegyver kezelésének elsajátítása és gyakorlása, a gránátlövésnél fellépő erőhatásokhoz való szoktatáshoz voltak megfelelőek.

A PGR-GY második változata NIKE 12-es riasztó hangjelző tölténnyel tölthető eszköz, amelynek ehhez módosított gyújtója (15. ábra) van. A PGK-GY gránátoknál az éles hajtómüben vak DC-1M gyújtó található.

\section{5. ábra. PGR-GY gyújtó}

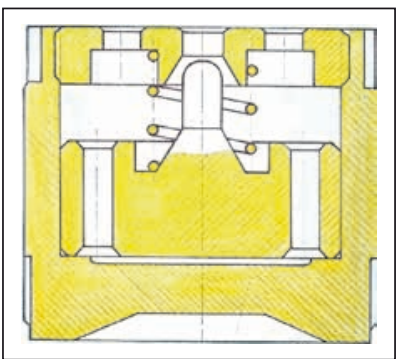

\section{EGYÉB GRÁNÁTOK}

A fentebb említett gránátokon kívül sok egyéb fejlesztés is történt a gránátok terén. A KFPG könnyfakasztó puskagránátot karhatalmi feladatokra fejlesztették ki. A KFPG gránátokból több sorozatot is legyártottak a Munkásőrségnek és a Belügyminisztériumnak. Kísérleti fázisban volt a lövedékcsapdás indítású indítócsővel rendelkező gránát is, amelyet 43M PSz karabélytölténnyel lehetett indítani. A kísérletek sikeresek voltak, az ilyen indítású gránátok indítócsöveiről vizsgálati céllal metszetek is készültek, de végül nem rendszeresítették azokat. Tervben, illetve korai kísérleti fázisban volt még több gránáttípus is, legjelentősebb képviselőik a napalm-, a ködgránátok voltak.

\section{ÖSSZEHASONLITÁSOK}

HSN (hátrasiklás nélküli) fegyverekkel való összehasonlításánál, például a kézi páncélelhárító gránátvetőkkel (pl. RPG-7-es), sokszor arra a következtetésre juthatnánk, 
hogy a puskagránát fölösleges, hiszen a HSN kézi páncélelhárító eszközök sokkal jobb hatótávolsággal és páncélrombolási képességgel rendelkeznek. Azonban fontos a működésből adódó jelenségek, a fiziológiai hatások, a harcászati mozgékonyság, az önvédelmi képesség, a rajban elfoglalt hely elemzése is. A kézi páncélelhárító gránátvető eszköz rajfegyver két főből álló kezelőszemélyzettel (kollektív lőfegyver), amely az irányzóból és a segédirányzóból áll. Az irányzó fegyvere a kézi páncélelhárító gránátvető és pisztoly, a segédirányzóé gépkarabély. A puskagránátvető gépkarabély egyéni lövészfegyver. Rendeltetésük is merőben különbözik. A kézi páncélelhárító gránátvető rendeltetése az ellenséges páncélozott eszközök pusztítása, a puskagránátvető gépkarabélyé pedig az ellenséges könnyen páncélozott eszközök, könnyű fedezékek pusztítása (kumulatív gránát), illetve az ellenséges élőerő pusztítása (repeszgránát), a saját erők rejtése (ködgránát) stb. Az egyik eszköz egy külön szakfeladatot lát el, a másik pedig kiegészíti a lövész képességeit.

Egyszerű példaként nézzük az PRG-7-es kézi páncélelhárító gránátvető $P G-7 V$ kumulatív gránátját és az AMP puskagránátvető gépkarabély $P G K$ kumulatív gránátját (3. táblázat).

\section{3. táblázat. PG-7V, PGK (16. ábra) összehasonlítás}

\begin{tabular}{|l|l|l|}
\hline \multicolumn{1}{|c|}{ Fegyver } & \multicolumn{1}{c|}{ RPG-7 } & \multicolumn{1}{c|}{ AMP } \\
\hline Gránát & PG-7V & PGK \\
\hline $\begin{array}{l}\text { Átütés } 90^{\circ} \text {, homogén } \\
\text { páncéllemez }(\mathrm{mm})\end{array}$ & 260 & 212 \\
\hline Hatótávolság $(\mathrm{m})$ & 500 & 150 \\
\hline Fej-átmérő $(\mathrm{mm})$ & 85 & 62 \\
\hline Tömeg $(\mathrm{kg})$ & 2,2 & 0,67 \\
\hline Tűzgyorsaság (1/min) & $4-6$ & 4 \\
\hline Maximális sebesség $(\mathrm{m} / \mathrm{s})$ & 300 & 93 \\
\hline Pásztázott lőtávolság $(\mathrm{m})$ & 330 & 117 \\
\hline Lőszerkészlet $(\mathrm{db})$ & $\begin{array}{l}8(17,6 \mathrm{~kg} \\
2 \text { főnél 3+5) }\end{array}$ & $3(2,01 \mathrm{~kg})$ \\
\hline
\end{tabular}

Amennyiben csak azokat az adatokat nézzünk, amelyek a konkrét páncélozott jármű elleni hatékonyságot mutatják, akkor valóban jobbnak mutatkozik a PG-7V gránát. Vizsgáljuk meg a lövész terhelését a két eszköznél. Az adatok szerint, két fő AMP gépkarabéllyal felszerelt lövész által hordozott tömeg 7 kg-mal kisebb, az RPG-7-es kézi páncélelhárítóval felszerelt tűzpárnál. Továbbá az AMP gépkarabélyos katonák $150 \mathrm{db} 43 \mathrm{M}$ PSz tölténnyel többel, viszont 2 db gránáttal kevesebbel rendelkeznek.

Vessünk össze néhány fontosabb biztonsági rendszabályt. Az RPG-7-es kézi páncélelhárító gránátvetőnél a gránátvető mögött 30 méteren belül tilos élőlénynek tartózkodni, üzemanyagot, lőszert, robbanóanyagot elhelyezni, a

16. ábra. PG-7V (felül) és PGK (alul) gránátok (hozzávetőlegesen méretarányos)

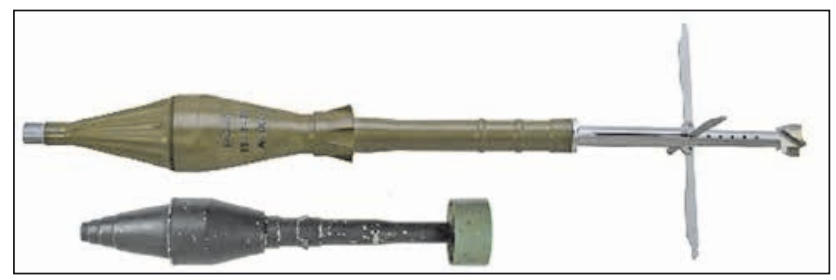

gránátvető mögött tilos 2 méteren belül akadálynak lenni, tüzeléskor tilos a csőtorkolatnak $20 \mathrm{~cm}$-nél közelebb lenni a talajhoz, a lövőnek $45^{\circ}$-os szögnél kisebb szögben elhelyezkedni a fegyver hossztengelyéhez képest.

Az AMP gépkarabélynál tilos éleslőszerrel gránátot indítani, tilos nyitott gázcsappal gránátot lőni, tilos a csőtorkolatnak $15 \mathrm{~cm}$-nél közelebb lenni tereptárgyhoz, tehát a hasonló vonatkozó biztonsági rendszabályok sokkal enyhébbek. Tehát harcászati helyigénye a puskagránát lövésnek jelentősen kisebb, és nem veszélyezteti a lövészkatonákat.

A cső alatti gránátvetők (4. táblázat, 17. ábra) talán közelebb állnak a puskagránátlövő gépkarabélyokhoz, mint a HSN fegyverek, hiszen szintén a lövész képességeit növelik. A cső alatti gránátvetők általában a mellső ágy alá csatlakoztatható szerkezetek. Önálló csővel, elsütő-szerkezettel rendelkeznek, kiszolgálásuk általában hátultöltő rendszerű egylövetű. Előnyük, hogy ugyanakkora terhelésnél a lövész több gránát szállítására képes, mint a nagyobb tömegű puskagránátoknál. Viszont jelentős hátrányuk a fegyver többlettömege, amely a külön szerkezetből álló gránátvető miatt lép fel. A példának állított gránátvetők az amerikai hadseregben rendszeresített M203-as cső alatti gránátvető és az orosz GP-25-ös, cső alatti gránátvető. Mind a két típus 40 mm-es, gépkarabélyra szerelhető gránátvető, amely arra hivatott, hogy a lövésznek olyan képességet adjon, amellyel eredményesebben veheti fel a harcot az ellenséges könnyen páncélozott célokkal, és nyíltan elhelyezkedő élőerővel szemben.

Manapság talán ez a legelterjedtebb kiegészítője a lövészrajoknak, amelyet a keleti és nyugati szomszédok arzenáljában egyaránt megtalálunk. Szimpatikus a viszonylag nagy, és könnyen hordozható lőszerkészlet. A gránátok könnyűek, kicsik, könnyen kezelhetők. A vető üzemeltetésénél csak alap lövészeti rendszabályok betartására kell szorítkozni a gránát biztonsági előírásain kívül, illetve a fegyverben sem igényel konstrukciós változásokat.

A táblázatból jól látható, hogy a puskagránát nagyobb hatással rendelkezik a könnyen páncélozott harcjárművek ellen, területtűz lövésére hatásosabb. Ez nem meglepő, hiszen a PGR gránát átmérője az AMP esetében 10 mm-el nagyobb (ebből adódóan a térfogata is jelentősebb, ami nagyobb mennyiségű robbanóanyagot jelent). A lövész teljes terhelésében (lőszerkészlet, vető és alapfegyver össztömege) nem mutatkozik jelentősebb eltérés. A hátraható energiák viszont - a cső alatti gránátvetők esetén - az éles lövésnél fellépőknek csaknem 6-8-szorosai. Így a lövész igénybevétele jelentős a cső alatti gránátvetőknél nem alkalmazott amortizátorok hiánya miatt.

A puskagránátokkal való összehasonlításnál (5. táblázat) a repesz és a kumulatív gránátok közül egy nyugati állam, egy keleti blokkhoz tartozó állam és az AMP puskagránátját vetettük össze.

Egyértelműen látszik, hogy a többi, rakéta póthajtás nélküli puskagránát kezdősebessége, ezáltal lőtávolsága is messze elmarad az AMP puskagránátjaiétól. Ez laposabb röppályát és nagyobb pásztázó lőtávolságot is eredményez, amely harcászatilag meghatározó jelentőségű. A rakéta póthajtás gyenge pontja a pontossága, mivel a póthajtás nélküli gránátok egy nagyságrenddel pontosabbak.

A kumulatív átütési szempontból a vizsgált nyugati gránát jobb eredményeket produkál, viszont ezt csak közelebbről tudja érvényesíteni, pásztázó lőtávolsága is elmarad a PGK-nál tapasztaltaktól. A repeszgránátoknál a sebesség- és lőtávolság-eltérés ugyanúgy a PGR puskagránát javára tapasztalható. Emellett az alkalmazott toldat miatt a PGR puskagránát repeszhatása is nagyobb. 
4. táblázat. Összehasonlítás cső alatti gránátvetőkkel

\begin{tabular}{|c|c|c|c|}
\hline Vető & GP-25 & M203 & AMP \\
\hline Gránát & VOG-25 & M406 & PGR \\
\hline Gránátvető irányzék & Ráépített & MWS M203 & $\mathrm{GO}-1$ \\
\hline Ürméret (mm×mm) & 40 (hüvely nélküli) & $40 \times 46$ & - \\
\hline Hatótávolság (m) & 400 & 350 & 450 \\
\hline Legnagyobb átmérő (mm) & 40 & 40 & 50 \\
\hline Gránátvető tömeg (kg) & 1,5 & 1,35 & - \\
\hline Gránátvető irányzék tömeg (kg) & - & 0,10 & 0,77 \\
\hline Gránát tömeg (kg) & 0,25 & 0,23 & 0,65 \\
\hline Tűzgyorsaság (lövés/perc) & $4-5$ & $5-7$ & 4 \\
\hline Hatásos sugár (m) & 6,8 & 5 & 12 \\
\hline Lőszerkészlet (gránát) (db) & 10 & 12 & 5 \\
\hline Gránát kezdősebesség (m/s) & 76,5 & 76 & 43 \\
\hline Maximális gránátsebesség (m/s) & 76,5 & 76 & 93 \\
\hline $\begin{array}{l}\text { Teljes tömeg, a cső alatti gránátvetők esetén az AMMSz } \\
\text { alapfegyverrel }(\mathrm{kg})\end{array}$ & 5,42 & 5,37 & 4,48 \\
\hline Gránátlövésnél fellépő impulzus (Nm) & 19,13 & 17,48 & 27,95 \\
\hline Fegyver hátrasiklási sebessége (m/s) & 3,53 & 3,25 & 6,23 \\
\hline $\begin{array}{l}\text { Hátraható energia, a cső alatti gránátvetők esetén az AMMSz } \\
\text { tömegéhez adva a vető tömegét }(\mathrm{J})\end{array}$ & 33,75 & 28,44 & 87,11 \\
\hline
\end{tabular}

\section{5. táblázat. Puskagránátok összehasonlító táblázata}

\begin{tabular}{|l|c|c|c|c|c|c|}
\hline \multicolumn{1}{|c|}{ Típus } & \multicolumn{3}{c|}{ Kumulatív } & \multicolumn{3}{c|}{ Repesz } \\
\hline Gránát & M31 & PGN-60 & PGK & F1N-60 & M63B & PGR \\
\hline Ország & USA & POL & HUN & POL & SPA & HUN \\
\hline Lőszer tömeg (kg) & 0,68 & 0,58 & 0,67 & 0,63 & 0,5 & 0,65 \\
\hline Legnagyobb átmérő (mm) & 76 & 68 & 62 & 55 & 40 & 50 \\
\hline Hatótávolság (m) & $75-115$ & $60-80$ & $100-150$ & 240 & 425 & 450 \\
\hline Maximális sebesség (m/s) & 60 & 58 & 93 & 54 & 75 & 93 \\
\hline Leküzdési sugár (m) & - & - & - & 7 & 6 & 12 \\
\hline Páncélátütés, 90 (mm) & 254 & 180 & 212 & - & - & - \\
\hline Pásztázó lőtávolság (m) & 65 & 61 & 117 & - & - & - \\
\hline
\end{tabular}

17. ábra. M203-as (balra) és GP-25-ös (jobbra) cső alatti gránátvetők. (Nem méretarányos)

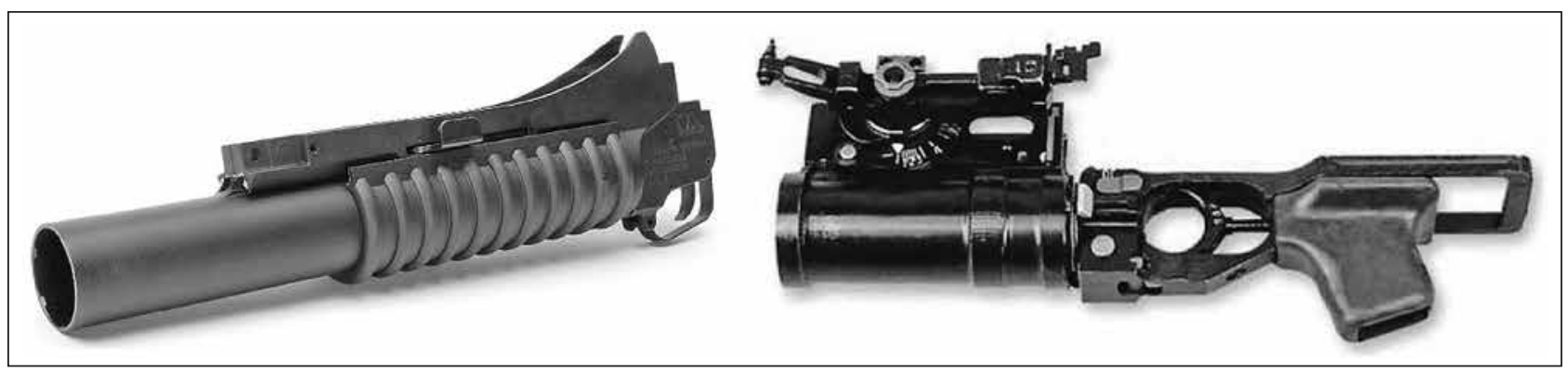




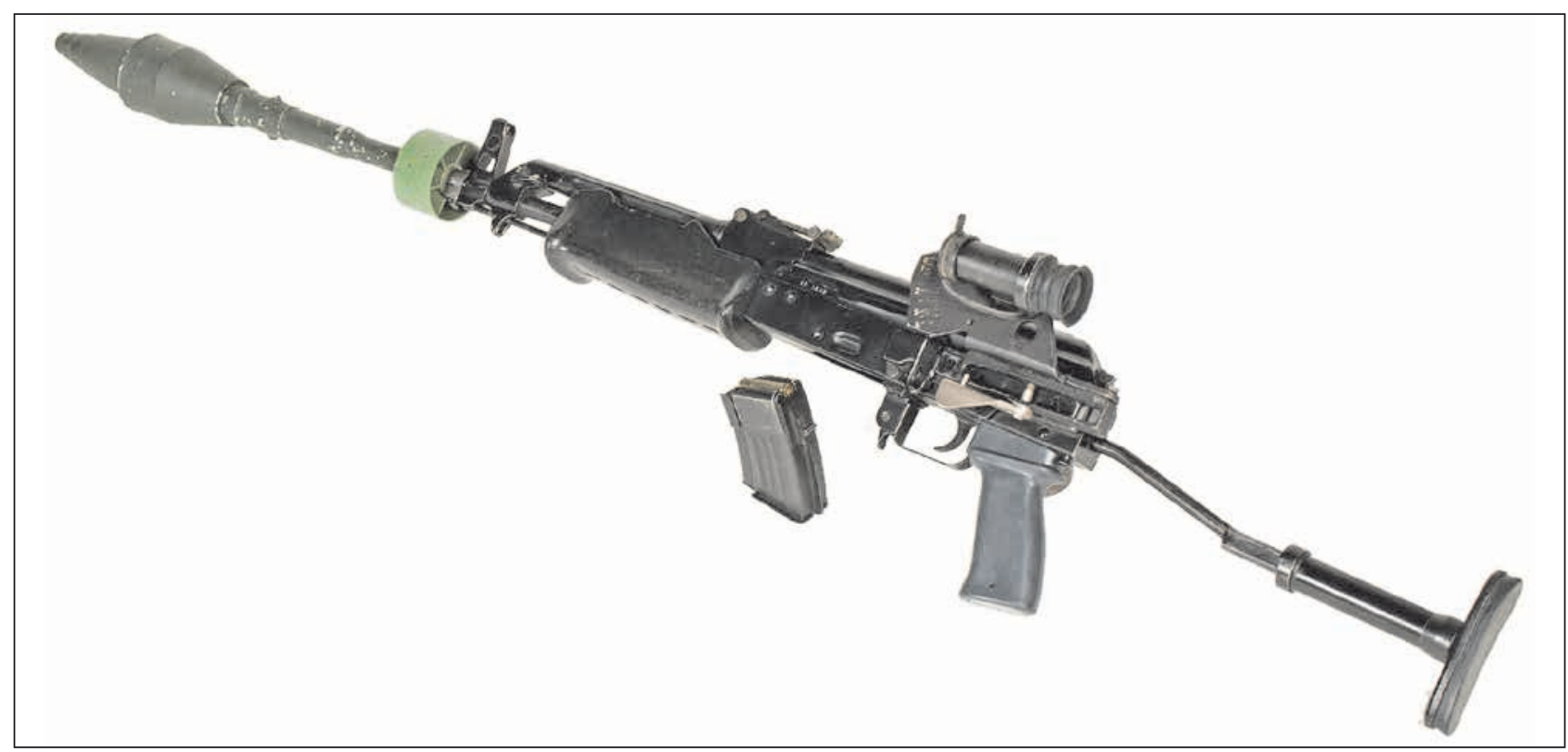

18. ábra. AMP puskagránátlövő gépkarabély PGK puskagránáttal, és kilövőtölténnyel töltött 6-os tárral

\section{Összegzés}

A bemutatott konstrukció természetesen nem lehet tökéletes. Léteztek jelentősebb fejlesztési irányok is, közöttük az automatikusan elzáródó gázelzáró csapszerkezet, az éleslőszerrel indítható lövedékcsapdás gránát, különböző gyújtó (napalm), ködösítő (ködgránát) és könnyfakasztó harcanyagokkal töltött gránátok és még sok hasonló kísérleti jellegű kiegészítés.

A 2000-es években a gépkarabély modernizációs program keretén belül készült egy áttervezett AMP modifikáció, amelyből jelenleg egy darab prototípus létezik.

A korabeli nyugati fegyverek nagy része már képes volt puskagránát indítására kilövőtölténnyel, vagy éleslőszeres indítással. Az AMP fejlesztése sürgetetten folyt, prototípus fázisban rendszeresítették, így nem róhatók fel egyértelmű konstrukciós hibaként a fegyver gyermekbetegségei (a válltámaszrögzítő-retesz nehéz oldása, gázelzáró csapszerkezet zárási problémák a kúposság pontatlansága miatt stb). A Munkásőrségnél is ebben a félkész állapotban rendszeresítették, így természetesen nem használhatták ki a fejlesztés teljes potenciálját. A rendszer továbbfejlesztése is minduntalan falakba ütközött, ezért a kedvezőtlen körülmények miatt a Honvédelmi Minisztérium vezetése feladatai meghatározásában - nem találta szükségesnek ennek a képességeknek az integrálását a lövészrajok szervezetébe. A fegyver tényleges rendszeresítését és elterjedését számos tényező gátolta hazánkban, például a Honvédelmi Minisztérium Fegyverzeti Csoportfőnöksége a fent említett okok miatt.

Végeredményként megállapítható, hogy az AMP puskagránátlövő gépkarabély (18. ábra) nem egy „legenda” vagy „AK csökevény”, hanem egy olyan fegyver, amely méltán kapott elismerő pillantásokat a nyugati országoktól is az 1970-es évek végén. Emellett a puskagránátlövő gépkarabély a Magyar Honvédség harcrendjébe, szabályrendszerébe könnyen beilleszthető, nem túlzottan nagy kiképzési erőforrás igényű, a gépkarabéllyal felszerelt lövész képességeit kiegészítő lőfegyver.

Az említett hibák ellenére világviszonylatban is elismerten jó fegyvert állított elő a fejlesztőgárda. Az AMP puskagránátlövő gépkarabély jelentős ergonómiai és modula- ritási módosításokkal, de a harcászati-műszaki követelményeket tekintve több mint 40 évvel fejlesztése után is megállná a helyét.

\section{IRODALOMJEGYZÉK}

40-mm grenade launcher M203 FM 3-22.31, FM 23-31.

Headquarters Department of the Army, 2003.;

7,62 mm-es AMD-65 géppisztoly leírása és kezelési utasítása. A Honvédelmi Minisztérium Kiadása, 1968.;

A 7,62 mm-es AK 63F (AMM) és az AK 63D (AMMSz) gépkarabély javítási utasítása. Az MH Fegyverzettechnikai Szolgálatfőnökség Kiadványa, 1999.;

A 7,62 mm-es AMP puskagránátlövő géppisztoly harcászati alkalmazása. Munkásőr parancsnokság, 1977.;

A 7,62 mm-es AMP puskagránátlövő géppisztoly leírása, kezelési utasítása. Munkásőr parancsnokság, 1977.

Gyalogsági fegyvergyártás technológiai fejlesztése Magyarországon 1935-1980. Honvédelmi Minisztérium Fegyverzeti Szolgálatfőnökség, 1980.;

Lőutasítás az RPG-7 és RPG-7D kézi páncélelhárító gránátvetőhöz. A Honvédelmi Minisztérium Kiadása, 1970.;

Руководство по 40-мм подствольному гранатомету гп-25. Военное Издательство Министерства Обороны СССР, Москва, 1983.;

Segédlet a 7,62 mm-es AMP puskagránátlövő gépkarabély harcászati alkalmazásához. Munkásőr Parancsnokság Hadmúveleti Osztály, 1984.;

Dobó Géza: Puskagránátok. Haditechnikai Szemle 1974/3, Haditechnikai Intézet, Budapest, 1974.;

Egerszegi János: A puskagránátok fejlődése. Haditechnikai Szemle 1976/1. Haditechnikai Intézet, Budapest, 1976.;

Egerszegi János: A puskagránátok fejlődése. Haditechnikai Szemle 1987/3. Haditechnikai Intézet, Budapest 1987.;

Egerszegi János: Egyéni sorozatlövő fegyverek fejlesztési lehetőségei, Haditechnikai Füzetek 4. szám. HM Technológiai Hivatal, Budapest. 